\title{
Climate Change and U.S. National Security
}

by Michael Andregg, University of St. Thomas in St. Paul, Minnesota, USA

mmandregg@stthomas.edu

\section{Overview}

In October of 2014 the U.S. Department of Defense published an "Adaptation Roadmap" for climate change that started with: "Climate change will affect the Department of Defense's ability to defend the Nation and poses immediate risks to U.S. national security." 1 Then Secretary of Defense Chuck Hagel was quoted saying: "Climate change does not directly cause conflict, but it can significantly add to the challenges of global instability, hunger, poverty, and conflict. Food and water shortages, pandemic disease, disputes over refugees and resources, more severe natural disasters - all place additional burdens on economies, societies, and institutions around the world." 2

This chapter will detail what those challenges and burdens are, with emphases on national security implications and consequences for U.S. Army personnel in particular. But it cannot and should not be narrowly focused, because this is a global problem with global consequences that affect the entire U.S. military. It affects alliances, flashpoints, basing issues, geopolitics and budgets in complex ways we will try to exemplify with specific cases, like Syria and South Asia.

Propaganda can influence assessments in any war zone. So that is not new, but it is an especially pernicious problem with climate change. ${ }^{3,4,},{ }^{6},{ }^{7}$ For example, at Minnesota's leading public policy institute ${ }^{8}$ we have been talking about, and some studying, climate change since at least 1982. It took 31 years before Andy Marshall commissioned the first publically known, 
Pentagon study of national security implications of climate change in $2003 .{ }^{9}$ Yet this author was told personally at the National Intelligence University in 2005 that officers there had been "ordered not to talk about that subject." This was all because of a sustained campaign by legacy industries to suppress discussion of something profound that they already knew was guaranteed to occur.

So let me be crystal clear, as a scientist, about a couple of key things up front. 1) Current climate changes are absolutely real, they are mostly caused by human actions in the modern era, and they are very significant in many ways not least of which are national security effects. 2) Scientific consensus on these and many derivative effects that will be itemized soon was achieved at least a decade ago, but reaction to the hundreds of warnings issued has been stalled by that persistant propaganda campaign, and by wishful thinking among small-minded politicians in the pockets of short-sighted legacy interests. There is zero real, scientific dispute except on margins like how quickly the Arctic and Antarctic ice sheets are melting and how fast therefore, the oceans will rise.

The rising seas pose immediate and very expensive challenges to the U.S. Navy since, naturally, most of their bases are on seashores. Some very important ones, like Diego Garcia in the Indian Ocean, sit mere feet above current sea levels (4 feet). ${ }^{10}$ Anyone can build a wall to restrain a foot of rising water, but building physical structures to restrain 20 feet of surges during cyclones or hurricanes is an entirely different challenge as New Orleans learned during hurricane Katrina. Furthermore, the ocean is becoming more acidic as it rises due to increasing levels of carbon dioxide in the warming water. This, plus the warming water, is killing coral reefs all over 
the world at this time. Reefs currently protect many other areas like the island of Guam, home to one of America's most important Pacific military bases. Reefs also help to feed a hungry world. So when reefs fail, people suffer and eventually move. When large numbers of desperate people move, smaller conflicts can escalate into wars.

The U.S. Air Force uses those island bases as much as our Navy, and half of their work supports U.S. Army operations in desert countries far away. There are also major climate change effects much closer to home. MacDill Air Force Base in Tampa Bay, Florida, is home for the U.S. Central Command (CENTCOM) and is extremely vulnerable to hurricane damage, as are many other military bases in Florida and along the Gulf coast. U.S. Southern Command (SOUTHCOM) was based at Homestead Air Force Base in Miami, until Hurricane Andrew wiped that off the operational map in 1992, which cost the Air Force billions to rebuild.

Even Offutt AFB in Nebraska, home to STRATCOM, which controls our nuclear forces, had to close in April of 2019, because of climate change enhanced flooding. ${ }^{11}$

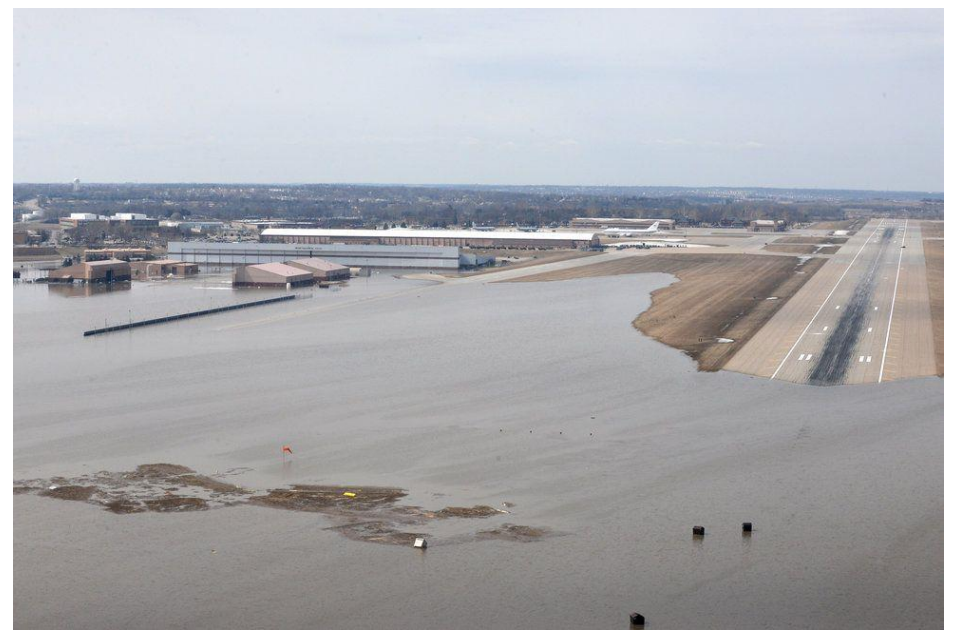

One of several photos taken by the Offutt Air Force Base Commander to illustrate why STRATCOM had to "close" for a while. You know something big is happening with the weather when three major U.S. Commands have to adjust in such dramatic and expensive ways. 
Yet intelligence personnel with abundant clearances were "forbidden to discuss this subject" at the National Intelligence University in 2005, then based inside the DIA's Defense Intelligence Analysis Center at an Air Force Base near D.C.. That is insanity run through an obedient bureaucracy. And this was not an isolated incident; it is part of a recurring pattern. ${ }^{12}$

So, without further digressions to deal with pernicious propaganda and willful ignorance, let me be blunt about the most important consequences of climate change for the United States of America and the U.S. Army in particular.

1. By far the biggest effect is that climate change drives new conflicts, especially in desert countries, and exacerbates existing conflicts. This is one of several reasons why we are currently bogged down in forever wars that do not end. Meanwhile, other powers rise. ${ }^{13}$

2. Climate change is also expensive in many ways, some obvious like the costs of relocating military bases (much less entire cities like Miami someday), and some much less obvious like the costs of crop failures and emergent diseases in more places on earth each day. When national economies suffer, military budgets suffer, and some of those resources must be diverted to increasingly common and expensive "natural" disasters.

3. Mass migrations have already destabilized politics in Europe, for one example, and in Central America for another. Failed or failing states export desperate people to near neighbors, as when Syria disintegrated, sending over six million to Turkey, Lebanon and 
Jordan. Over one million went on to far away Europe with huge political consequences.

The U.S. Army may not want to be involved in such disasters, but I guarantee it will be.

\section{A Short List of Climate Change Effects Today:}

1. Increasing carbon dioxide (and other 'greenhouse gasses') in the atmosphere trap heat, thus increasing average air temperatures (worldwide, but with considerable variability).

2. Hotter air and infrared radiation warms the oceans, which then expand and slowly rise.

3. This also results in ice melting at both poles and almost all glaciers. That results in more rise of ocean levels. Worst-case scenarios could mean much greater consequences. ${ }^{14}$

4. Hotter air means more evaporation, which means slowly increasing precipitation and altered high level wind flows. Both of these effects can dramatically impact agriculture.

5. Hotter air and water creates more precipitation, and results in more and fiercer storms. Hurricanes and cyclones have especially large effects on basing and security issues. ${ }^{15}$

6. The ranges of agricultural pests are moving north (in the Northern Hemisphere) as are optimal zones for growing crops. Large areas are "desertifying" like regions of Syria and sub-Saharan Africa that once were productive. These result in massive migrations and occasional genocides as we saw in Darfur, ${ }^{16}$ or ethnic "cleansings" as in Myanmar. ${ }^{17}$ 
7. There are also major public health implications as once-tropical diseases spread north. Mosquitoes are the most important pests, because they are vectors for many diseases like malaria, Zika, and West Nile virus. But public health professionals also worry about "emergent diseases" like SARS, MERS and nightmares like ebola. These too can destabilize nations. Africa will be the hardest hit, but Africa connects to everywhere.

8. There are more and fiercer wildfires in North America and Southeast Asia, especially where forests are stressed for other reasons. In desert zones like the Middle East, conflicts over water can result in actual wars that the US gets involved in, but cannot end.

9. Oceans are also becoming more acidic, with major effects on shellfish and other foods. ${ }^{18}$

All of these items are certain to occur, even if population growth were to stop tomorrow. But that is not going to stop anytime soon, ${ }^{19}$ and population growth is a major driver of climate change, ${ }^{20}$ because most people want to consume food and water. That uses energy. Growing middle classes in Asia and Africa also want better things like refrigeration, air conditioning, transportation and modern medicines, all of which require large amounts of energy to produce.

These nine items therefore have national security consequences too, not least increases in the cost of operations in hostile environments and diversion of military resources to ever more humanitarian rescue missions. Such disasters often coincide or collocate with armed conflict zones, wearing out equipment and personnel. We have been dealing with symptoms of a global crisis for decades, rather than with ultimate causes. One does not need a degree in medicine to know that this is unwise. The military analogue is winning all the battles, but losing the wars. 


\section{The Case of Syria}

Syria and the rise of ISIS exemplify these difficult problems pretty well, but most current discussion focuses on the personalities of key leaders like Bashar al-Assad or Abu Bakr alBaghdadi, and the role of militant Islam. Those are relevant, of course, and must be dealt with regardless of efforts to get at ultimate causes. But focus on the obvious things, like triggering events and political leaders, often obscures the ultimate causes of large scale armed conflicts.

The case of the disintegration of Syria from 2011 to the present day is particularly vivid and has more reliable metrics than many, so we will concentrate on that case here. In 2010, the population growth rate in Syria was $2.4 \%$ per year. ${ }^{21}$ This leads to a doubling time of just under 30 years ${ }^{22}$ and a highly "pyramidal” age distribution with many more young than elders. ${ }^{23}$ That matters because pyramidal age distributions have momentum. Even if birth rates plunge suddenly, such populations will continue to grow for decades unless death rates soar. The CIA's estimate of Syria's age distribution for 2018 is shown below. They also note a total population that year of 19.5 million. This is many millions LESS than when their civil wars began. 


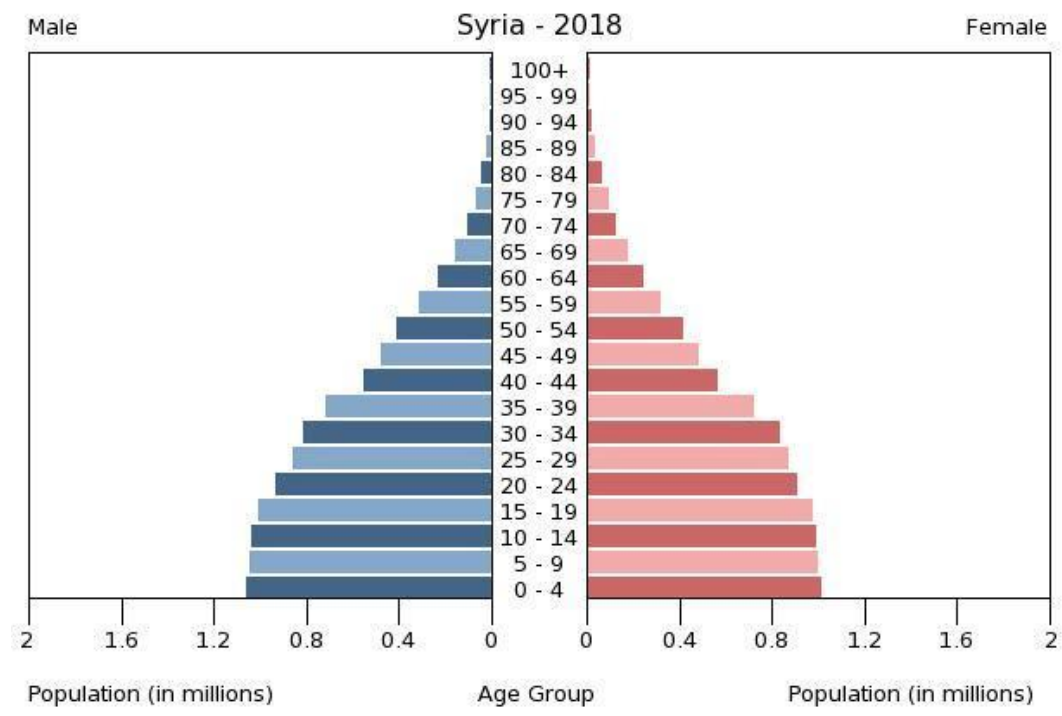

This image is from the CIA's World Factbook, one of the best sources in the world for global demographic data (others are the UN and the World Bank).

Mentioned much less often, but relevant to climate change issues, the worst drought in Syria's recorded history occurred during the four years prior to onset of the war, leading to migration of at least 1.5 million (of Syria's then 24 million people) from barren farmlands into overburdened cities. ${ }^{24}$ Climate change almost certainly contributed to that drought, and global warming is a substantial and significant consequence of the global increase in human populations and consumption of fossil fuels. Climate change is a derivative result of population pressure.

Syrian conflicts began with simple protests, largely of students in Damascus, who sought a fairer distribution of job opportunities from the government of Bashar al-Assad. ${ }^{25}$ Assad was reserving the best for his Alawite ethno-religious group, with some for minority Christians in a predominantly Sunni country. Assad followed in his father's footsteps by crushing protests, which introduces two other ultimate causes of wars, corruptions of governance and authoritarian law. But this time, the tidal force of population pressure combined with militant religion, which was growing throughout the region. So, despite many casualties, protests endured, and became 
more militant and better armed. This morphed over a few years into a hyper-complex and brutal series of civil wars in which ISIS played a prominent role. That led to over half a million dead, half of the pre-war Syrian population displaced, and at least 6 million refugees who fled to near neighbors (>1 million went on to Europe) spreading population pressure to all those areas. Burdens were especially great on fragile Lebanon, Jordan and increasingly militant Turkey. ${ }^{26}$ Meanwhile, the Alawite population in Syria grew from $11 \%$ in 2010 to about $17 \%$ in $2014 .{ }^{27}$

What do all these demographic numbers mean for U.S. Army operations in desert conflict zones? The most important point is that if the population in distress continues to grow it can generate almost unlimited numbers of unemployed and largely unemployable teenaged males. Demagogues abound in such places, eager to blame their distress on evil foreign "others," like us. Of course, we have the capacity to kill large numbers of these desperate and misguided men. But if we do not get past the tactical level of killing unemployed men to deal with strategic causes of conflict, we are doomed at best to live with very expensive and painful 'forever wars.'

While the U.S. was directly involved in defeating ISIS in Iraq, our exposure in Syria was mainly support of local forces. The U.S. declared an official "end" to ISIS territorial dominance on March 23, 2019 when Baghouz, Syria was overrun by Kurdish forces supported by U.S. air power and special operations forces. However, the pros all know that the conditions that gave rise to ISIS remain. ${ }^{28}$ The malignant leader of ISIS, Abu Bakr al-Baghdadi, has disappeared along with very large sums of money. ${ }^{29}$ The desert that gave rise to those millions of desperate teenaged males will not grow new wealth unless someone invests heavily in that. And the forces of climate change detailed previously work against current deserts blooming anytime soon. 
Meanwhile, considerable population pressure was transferred to Turkey in the form of about 3.6 million refugees. ${ }^{30}$ They are also not going anywhere soon, and Turkey’s economy is struggling with its own issues. Droughts and changing weather patterns that adversely affect agriculture can happen anywhere, and failed states can spread like a contagion.

\section{Bangladesh, Myanmar and South Asia more Generally}

Bangladesh is known for very large numbers of people and abject poverty. But it also contains the largest river delta in the world, and one of the most fertile agricultural regions on earth. Of greatest relevance to this chapter is the fact that most of that Ganges-Brahmaputra Delta lies within feet of sea level. Therefore, if sea levels rise significantly, vast amounts of very productive farmland will be ruined by salt water, and tens of millions of people will need to find new homes in a region that is already severely overcrowded and prone to conflict.

A much larger area is watered partly by runoff from glaciers and snow deposited on the great Himalayan Mountains and the Tibetan Plateau to the north. Large parts of Pakistan, India, Nepal, Bhutan, Myanmar, Vietnam and large parts of China benefit from this runoff. However, the glaciers there are melting fast, and the countries cited had a combined population in 2018 of about 4 billion people. China has a big advantage, because it controls the headwaters of many of the great rivers watering those areas, and of course, it has the largest Army by far. 
Kenneth Pomeranz discussed this watershed in 2009, its vulnerabilities to climate change and potentials for organized, armed conflict therefore. ${ }^{31}$ After noting the other great watersheds of the world, and conflicts in them over water, Pomeranz writes:

"But none combine the same scale of population, scarcity of rainfall, dependence on agriculture, scope for mega-dam projects and vulnerability to climate change as those at stake within the greater Himalayan region. Here, glaciers and annual snowmelts feed rivers serving just under half of the world's population, while the unequalled heights from which their waters descend could provide vast amounts of hydro-power. At the same time, both India and China face the grim reality that their economic and social achievements since the late 1940s-both 'planned' and 'market-based'-have depended on unsustainable rates of groundwater extraction; hundreds of millions of people now face devastating shortages."

One of the weakest countries in this complex is Myanmar (which the CIA still calls Burma if you are using the World Factbook for research). Myanmar has been afflicted with small, ethnic-based civil wars for decades. In August 2018, pressure from a rapidly growing, Muslim population in Southeast Myanmar called the Rohingya angered majority Burmese Buddhists. ${ }^{32}$ This resulted in many massacres and caused over 700,000 of a Rohingya population near one million to flee into Bangladesh. The United Nations described the military offensive in Rakhine province as a "textbook example of ethnic cleansing." 33

The United States military can stand by while other nations far away conduct ethnic cleansing or even genocide. It certainly cannot solve all the problems of the world, even though 
some would like us to be a "global police force." But we cannot ignore the fact that three of these countries are nuclear powers (China, India and Pakistan) all of which have had border wars in the last 20 years. The Pakistan-India dyad is especially unstable, and if they have a nuclear war, this could damage agriculture worldwide while destroying South Asia's economy at least. ${ }^{34}$

To the northeast, North Korea is facing off America over nuclear weapons development, while starvation haunts their land. ${ }^{35}$ In mid-2019, North Korea is experiencing its worst drought in decades with only 2.1 inches of rain to May 16. The United Nations has warned of an urgent food crisis unless massive food aid appears from somewhere. No one is eager to donate food to the most brutal police-state on earth today. But desperate nations sometimes do desperate things, and dictators are notorious for starting foreign wars to distract domestic discontent. When they have nuclear weapons, the entire world is at risk. So good luck with negotiations!

Therefore, we do not need to conjure worst-case scenarios like Pakistan giving or selling some of its warheads to Islamic extremists elsewhere to be very worried about where all this conflict is headed in a region whose population still grows substantially each year, while reliable water sources decline. South Asia is a powder keg today with potential to spread its problems worldwide. And climate change is one of the drivers that traditional analysts neglect at our peril.

\section{Novel or Exotic Consequences of Climate Change for Military Professionals}


Previous sections have focused on results of climate change that we can already see and measure. There are some more dramatic possible consequences of climate change that serious military professionals should know about for the same reasons we prepare for rare, but high impact military contingencies.

For example, current estimates are that sea levels may rise about one meter $(\sim 3.3$ feet $)$ by 2100. That is alarming, but manageable unless you are a country like Kiribati in the South Pacific. ${ }^{36}$ However, many of our recent estimates have been underestimates. Some people have also pointed out that if the Antarctic ice shelves collapse completely (the thinnest already have) ${ }^{37},{ }^{38}$ then sea level rise by 2100 could be as high as 20 feet. That would have much larger implications for Miami, Manhattan, San Diego and Honolulu, much less for countries like Bangladesh.

The North Pole presents different extreme dilemmas. First, when ice sheets melt, permafrost also melts, which increases decay releasing potentially vast amounts of methane. Methane is about 20 times more powerful a "greenhouse gas" than carbon dioxide. That could dramatically increase the pace of climate change through a positive feedback loop.

Second, whether nor not methane becomes important, the Arctic ice sheets are already retreating so fast that Canada and Russia in particular are mapping out northern sea routes for trade that were impossible to contemplate before global warming became an issue. This creates a large area for many more potential military conflicts than in the past. Russia, for example, has already claimed the North Pole, seeking primacy over mineral resources below it. ${ }^{39}$ 
We have already noted the Marshall Report of 2003 that considered an extreme scenario where major changes of ocean currents affect agriculture and much else worldwide. Such scenarios should be considered for the same reasons we study potential terrorist attacks at key locations. Likewise, national security implications of emergent, pandemic diseases should be studied carefully. Even ancient killers like the flu and smallpox could become more lethal and impactful. And who wants to deploy into a conflict zone like Eastern Congo where ebola is emerging again? As I write, the 22nd outbreak of ebola since 1977 is spreading rapidly, helped by armed attacks against the medical personnel trying to contain it. ${ }^{40}$ If ebola ever gets to a major population center like Kinshasa, Nairobi or Lagos, the world will never be the same.

By far the biggest wildcard is probably Africa. The fundamental reason for that is population growth, the taboo topic that underlies the entire climate change discussion. Today, the continent of Africa with its 54 countries has a population of about 1.3 billion people. By 2100, the UN estimates that Africa will contain over 4 billion people. ${ }^{41}$ That is quite a lot of population pressure in an area that already has half of the persistent civil wars on earth today. And ISIS, declared dead by President Trump on March 23, 2019, is spreading today in the Sahara and Sahel of northeastern Africa. ${ }^{42}$

AFRICOM may not want more business, but the Russians and especially the Chinese are all over Africa right now. Conflicts are endemic, and some are likely to get worse. It might be nice if we could build a big wall around Africa and ignore its problems, but those are fantasies. We must deal with the world as it is, which is interconnected. Our world is warming, and the 
living system that supports us all is already in great distress. ${ }^{43}$ Civilization itself depends upon that living system. Therefore, it is imperative that sensible people everywhere stop the denial, and start the large engineering and constructive biology projects that scientists have been urging for a generation now.

Otherwise, the global jihads we have been struggling with since at least 1991 will likely grow even larger, because failing states always seek a scapegoat for their failures.

\section{A Good Resource on Climate Change for Military Professionals}

While some intelligence professionals were "forbidden to discuss this subject," others saw the writing on the wall years ago and began to study military implications of climate change. Then, with a change of administrations, it became possible to talk seriously about national security implications of climate change and to publish subsequent reports. The best compilation I have seen was created by an "American Security Project" in their Climate Security Report of 2017, accessible at: https://www.americansecurityproject.org/climate-security . ${ }^{44}$

This report has seven major sections, including one on solutions, with over 50 subsections on military relevant topics. We will mention just three of those here to illustrate congruence between their work and my independent assessments. In section two on "Climate Change Threatens National Security" there are subsections on "Climate change threatens South 
Asian stability," and “Could the Syrian conflict be a symptom of climate change?" My answer to those two cases is an obvious and emphatic "yes."

In section four on how "The Military is Preparing for Climate Change" there are several subsections on the Arctic and on the relevant Quadrennial Defense Review. But of special interest is the section called "If military sees climate risk, why do we deny?" I have provided many references on that question, but it is imperative to recognize that organized and wellfunded campaigns to deny climate change continue. Some vested interests would rather make maximum profits today no matter how grave the consequences for our future and our children.

This is neither acceptable, nor wise. But it will continue, because entire civilizations take a long time to learn about difficult new problems, and vested interests are driven by many factors to consider mainly their own, short-term situations. Garret Hardin called this "The Tragedy of the Commons" in a landmark, 1968 article in Science. ${ }^{45}$ Therefore, I urge all readers to be aware of this ongoing factor that distorts clear thinking about a major threat to U.S. national security.

\section{Conclusions}

A nation that survived two World Wars, our own Civil War, and a 'Cold' War that threatened annihilation of everything can survive the challenges of climate change, severe though those are. To survive with minimal pain, however, requires some paradigm shifts in thinking about strategic threats to our country. 
A good example specific to the U.S. Army is in how Civil Affairs units are managed. Not long ago ${ }^{46}$ wizards at H.Q. decided to cut those units in half, and put the one remaining brigade under the Special Operations Command. There is a reasonable rationale for that if one ignores the factor of climate change, since SOCOM often operates in failed states that could benefit from a little 'nation building' after bad guys have been defeated.

That has not worked out very well, because building nations once destroyed is extremely expensive, very difficult, phenomenally frustrating, and requires very long-term investments that transcend political administrations. Furthermore, new terrorist threats are always emerging. Therefore, it is quite natural for forces that are focused on maximum lethality and stealth to look at Civil Affairs as a kind of junior adjunct to that urgent task of beating today's bad guys (who are undoubtedly very dangerous).

Therein lies the trap that has bogged us down in unwinnable 'forever wars' today. When we factor in the role of climate change and other strategic causes of organized armed conflict on earth today, quite a different picture emerges.

Nation building becomes far more important no matter how expensive that may be, and is. Therefore, Civil Affairs units become more important. This does not mean the Special Forces have no role. All those humanitarian missions need to be protected, because few terrorists have left the field, and the demagogues who point them toward us sprout like mushrooms on decaying 
logs. But it does mean that more attention must be paid to why the multitudes are so desperate, and how to defeat demagogues by better information operations more than by better bombs.

Another example could be the wisdom, or lack thereof, of investment in modernizing our nuclear forces. There are many obvious reasons to consider this, not least the fact that everyone else who has nuclear weapons is modernizing. Furthermore, some especially loathsome tyrannies want to join that club and proliferate nuclear weapons to their friends. Therefore, there are plenty of valid reasons for concern about nuclear issues today.

However, I would say that a bigger danger than mass attack from China, for example, is a single nuclear detonation in Tel Aviv accomplished by a terrorist group that bought a nuclear warhead on the black arms market, or was given one by sympathizers in Pakistan. Replace Tel Aviv with Washington D.C. if you prefer that scenario, or simultaneous detonations in D.C. and Moscow. The point is what happens after any of these major cities goes up in radioactive smoke.

Escalation chains are easy to describe, but notoriously impossible to predict. Most simulated WMD war games quickly escalate to general thermonuclear war. The U.S. Army has very few tools that could influence outcomes if worst-case nuclear scenarios come true. Prevention thus becomes essential. In fact, the main tools the Army could apply are before disaster strikes, specifically, 1) considerably increased information operations, and 2) those nation building things addressed by Civil Affairs units to reduce the chances that conflicts reignite after conventional or special forces have stopped any one especially dangerous threat. 
Therefore, from this perspective, it is imperative for the regular Army to hold a perimeter between civilization and barbarism that is hard even to define. Terrorists with nuclear weapons is just one obvious example of the manifold types of barbarism that threaten civilizations today. But if the Army can hold that perimeter, then other forces can work on the strategic causes of organized, armed conflict on earth today.

A medical metaphor could be dealing with gangrene. Ignoring gangrene is lethal, so that is not a realistic option. Controlling fever is essential, as sepsis spreads, but this is only dealing with a symptom not a cause. Therefore, someone must deal simultaneously with the source of the infection while keeping symptoms from killing the patient. Consider "terrorists" a form of "gangrene" for civilizations.

Therefore, unpleasant though these problems are, I say ignoring the problem of failed states is neither an honorable nor a realistic option for the U.S. Army. Rethinking our allocations of scarce resources away from Armageddon scenarios and maximum lethality toward actions that contain and then seek to prevent organized, armed conflict is the wiser path when possible.

Climate change is undoubtedly a big threat to U.S. national security today, as much because it challenges our historic paradigms as because it is huge, expensive, complicated, and cannot be killed. However, it is the duty of everyone who swears to preserve, protect and defend the U.S. Constitution to figure out how to deal with the emerging challenges of the third millennium of the Common Era. That will not be easy, but press on. 
1 “2014 Climate Change Adaptation Roadmap,” U.S. Department of Defense, accessible at: https://www.acq.osd.mil/eie/downloads/CCARprint_wForward_e.pdf

${ }^{2}$ Hagel, Chuck, U.S. Secretary of Defense, remarks delivered to the Halifax International Security Forum on Department of Defense Arctic Strategy, November, 2013.

${ }^{3}$ Hoggan, James, with Richard Littlemore, Climate Cover-Up: The Crusade to Deny Global Warming, Greystone Books, 2009, 2017.

${ }^{4}$ Oreskes, Naomi and Erik M. Conway, Merchants of Doubt: How a Handful of Scientists Obscured the Truth on Issues from Tobacco Smoke to Global Warming, Bloomsburry Press, 2010.

${ }^{5}$ McCarthy, Niall, "Oil and Gas Giants Spend Millions Lobbying to Block Climate Change Policies [Infographic]," in Forbes, March 25, 2019, accessible at: https://www.forbes.com/sites/niallmccarthy/2019/03/25/oil-and-gasgiants-spend-millions-lobbying-to-block-climate-change-policies-infographic/\#9e0917b7c4fb .

${ }^{6}$ Hope, Mat and Karen Savage, "Global Climate Coalition: Documents reveal how secretive fossil fuel lobby group manipulated UN climate programs," in DeSmogBlog, April 26, 2019, accessible at:

https://www.nationofchange.org/2019/04/26/global-climate-coalition-documents-reveal-how-secretive-fossil-fuellobby-group-manipulated-un-climate-programs/

${ }^{7}$ Kehoe, Paula, A Burning Question: Propaganda and the Denial of Climate Change, a 53 minute educational video produced by Earth Horizons Production, 2012.

${ }^{8}$ The Hubert H. Humphrey Public Policy Institute is located at the University of Minnesota where the author taught in various capacities for 35 years.

${ }^{9}$ Schwartz, Peter and Doug Randall, "An Abrupt Climate Change Scenario and its Implications for United States National Security," 2003, otherwise known as the "Marshall Report" because legendary Pentagon forecaster Andy Marshall commissioned it, is accessible at: https://grist.files.wordpress.com/2004/02/abruptclimatechange2003.pdf . ${ }^{10}$ Diego Garcia's average height above sea level is 4 feet. This major U.S. base supports Naval and Air Force operations throughout the Indian Ocean and as far away as Southeast Asia, Central Asia and the Middle East.

${ }^{11}$ The Center for Strategic and International Studies (CSIS) is a very well regarded national security think tank in Washington, DC, which sponsors a "Project On Nuclear Initiatives" (PONI) each year. Their capstone conference for 2019 had to move out of Offutt AFB due to exceptional flooding. The point is that climate change can affect any region on earth, including military bases in the core of America's heartland. More information can be found at: https://www.csis.org/programs/international-security-program/project-nuclear-issues/poni-publications

${ }^{12}$ Nuccitelli, Dana, "Millions of times later, 97 percent climate consensus still faces denial," in the Bulletin of the Atomic Sciences, August 15, 2019, accessible at: https://thebulletin.org/2019/08/millions-of-times-later-97-percentclimate-consensus-still-faces-

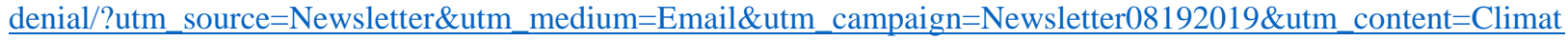
eChange ClimateConsensus 08152019.

13 The most obvious rising power today is China. Harvard professor and Pentagon consultant Graham Allison has been sounding alarms for years through a much-reviewed book called Destined for War: Can America and China Escape Thucydides's Trap? (2017). Whether Allison's theory is correct or not, there is zero doubt that China is expanding its leadership positions worldwide and its military strength rapidly while the U.S. spends vast sums and burns up huge amounts of military equipment in wars in the Middle East that have defied resolution for many years. ${ }^{14} \mathrm{By}$ 'much greater consequences' we mean things like sudden, 20-foot rises in sea level if large ice shelves in Antarctica or around Greenland collapse, or major ocean currents change as in the extreme scenario explored by the Pentagon's Marshall Report cited in endnote \#9.

${ }^{15}$ Milman, Oliver, “Are hurricanes getting stronger - and is the climate crisis to blame?" In The Guardian, May 20, 2019, accessible at: https://www.theguardian.com/world/2019/may/20/are-hurricanes-getting-stronger-and-is-the-

climate-crisis-to-

blame?utm term=RWRpdG9yaWFsX0d1YXJkaWFuVG9kYXIVUy0xOTA1MjA\%3D\&utm_source=esp\&utm_me dium=Email\&utm campaign=GuardianTodayUS\&CMP=GTUS email

${ }^{16}$ Darfur is an area in Western, desert Sudan that experienced the first genocide of the $21^{\text {st }}$ century when as many as a million people were murdered, raped or expelled from their homelands by forces aligned with Sudan's then President Omar Al Bashir. The International Criminal Court indicted several people including Bashir for crimes against humanity and other crimes in 2009 and 2010.

${ }^{17}$ Blomquist, Rachel and Richard Cincotta, "Myanmar's Democratic Deficit: Demography and the Rohingya Dilemma" in New Security Beat, Wilson Center's Environmental Change and Security Program, April 12, 2016, at: https://www.newsecuritybeat.org/2016/04/myanmars-democratic-deficit-demography-rohingya-dilemma/ . 
${ }^{18}$ National Oceanic and Atmospheric Administration, U.S. Dept. of Commerce, "Ocean Acidification," accessible at: https://www.noaa.gov/education/resource-collections/ocean-coasts-education-resources/ocean-acidification . ${ }^{19}$ The United Nations Demographic Division now estimates that the earth's human population will reach about 11 billion people by 2100 , as compared with 7.7 billion today. That is a huge increase in needs for all resources, not least energy, which is why the world agreed to a "Paris Climate Agreement" in 2016 that the USG currently spurns. ${ }^{20}$ The United Nations "Intergovernmental Panel on Climate Change" https://www.ipcc.ch/ was created to compile data on these issues in 1988. It publishes a biannual collection of research results from hundreds of studies worldwide. That work resulted in a Nobel Peace Prize in 2007 because of its implications for global security. ${ }^{21}$ CIA, World Factbook, 2010, section on Syrian population demographics.

${ }^{22}$ The rule of thumb formula for doubling times is 70 over the growth rate in percent, so a growth rate of $2.4 \%$ yields $70 / 2.4$ or a doubling time of 29.17 years. It is very difficult to double economies that fast, even when they are well managed and equitable, which most are not.

${ }^{23}$ An excellent reference for age distributions of populations is the CIA's World Factbook, at https://www.cia.gov/library/publications/the-world-factbook/. The important point about "pyramidal" age distributions is that they develop momentum, so that sudden downturns in, for example, agricultural production can result in immediate social stress and sometimes armed conflict if the agricultural decline is not quickly fixed.

24 "A Syrian Refugee at COP21," by Andrea Liverani, October 21, 2015, accessible at:

http://blogs.worldbank.org/peoplemove/syrian-refugee-cop21 .

${ }^{25}$ Encyclopedia Britannica editors, "Syrian Civil War," accessed April 28, 2019 and accessible at: https://www.britannica.com/event/Syrian-Civil-War

${ }^{26}$ UN High Commissioner for Refugees, "UNHCR Syria Regional Refugee Response/Total Persons of Concern." August 29, 2015, accessible at: https://data2.unhcr.org/en/situations/syria.

${ }^{27}$ CIA World Factbook, 2014, section on Syrian population demographics.

28 "The ISIS caliphate has ended, but its breeding ground thrives," CNN world report for March 23, 2019, accessible at: https://www.cnn.com/2019/03/23/middleeast/end-of-isis-caliphate-intl/index.html

${ }^{29}$ Gardner, Frank, "Abu Bakr al-Baghdadi: Why is it so difficult to track down IS leader?" in the BBC World News, May 1, 2019, accessible at: https://www.bbc.com/news/world-middle-east-48104463

${ }^{30}$ The UNHCR compiles data on Syrian refugees, by country. Their total for relocated to Turkey was 3,630,767 in April, 2019, which can be accessed at: https://data2.unhcr.org/en/situations/syria/location/113

${ }^{31}$ Pomeranz, Kenneth, "The Great Himalayan Watershed: Agrarian Crisis, Mega-Dams and the Environment," in the New Left Review \#58, July/August, 2009.

${ }^{32}$ Blomquist, Rachel, "Ethno-Demographic Dynamics of the Rohingya-Buddhist Conflict," in the Georgetown Journal of Asian Affairs, Fall, 2016, pp: 94-117. This is accessible at: https://asianstudies.georgetown.edu/sites/asianstudies/files/documents/gjaa 3.1_blomquist_0.pdf .

${ }^{33}$ BBC World News, "Myanmar Rohingya: What you need to know about the crisis," April 24, 2018, accessible at: https://www.bbc.com/news/world-asia-41566561.

34 "Nuclear Winter" is a theoretical consequence of even a few score nuclear detonations over large cities. All those burning hydrocarbons could dim light reaching the earth's surface for years, reducing agriculture near and far away.

${ }^{35}$ Choe, Sang-Hun, "In North Korea, Worst Drought in Decades Adds to Food Crisis," in the New York Times, May 16, 2019, accessible at: https://www.nytimes.com/2019/05/15/world/asia/drought-north-korea-foodcrisis.html?nl=todaysheadlines\&emc=edit th 190516 .

${ }^{36}$ Kiribati includes 33 low-lying atolls, three of which support people. Those islands average 6 feet above sea level at their highest elevation. Residents have already purchased land elsewhere, intending to move their entire 110,000 people since they know that their own nation is doomed. Denial is not practical when waves wash away your homes. ${ }^{37}$ Carrington, Damian, "'Extraordinary thinning' of ice sheets revealed deep inside Antarctica," in The Guardian, May 16, 2019, accessible at: https://www.theguardian.com/environment/2019/may/16/thinning-of-antarctic-icesheets-spreading-inland-rapidly-

study?utm term=RWRpdG9yaWFsX0d1YXJkaWFuVG9kYXIVUy0xOTA1MTY\%3D\&utm_source=esp\&utm me dium=Email\&utm campaign=GuardianTodayUS\&CMP=GTUS_email

${ }^{38}$ Curtain, Ashley, “'Thinned by extraordinary amounts:' Glaciers in Antarctica melting at accelerating rates," in Nation of Change, May 17, 2019, accessible at: https://www.nationofchange.org/2019/05/17/thinned-byextraordinary-amounts-glaciers-in-antarctica-melting-at-accelerating-rates/. This cites a new study published in Geophysical Research Letter by Andy Sheperd, et al, which relied on 25 years of satellite data from 1992 to 2007. 
${ }^{39}$ Kramer, Andrew E., "Russia Presents Revised Claim of Arctic Territory to the United Nations," in the New York Times, February 9, 2016. Accessible at: https://www.nytimes.com/2016/02/10/world/europe/russia-to-presentrevised-claim-of-arctic-territory-to-the-united-nations.html .

${ }^{40}$ PBS News Hour, "Congo's Ebola crisis threatens to spiral out of control," May 20, 2019, accessible at: https://www.pbs.org/newshour/show/congos-ebola-crisis-threatens-to-spiral-out-of-control .

${ }^{41}$ United Nations Demographic Division, "World Population Prospects: Key Findings and Advance Tables," 2015, accessible at: https://population.un.org/wpp/Publications/Files/Key_Findings_WPP_2015.pdf

${ }^{42}$ Essawi, Attia, "Sahel-Sahara: The next IS stronghold," in Al-Ahram Weekly, May 21, 2019, accessible at: http://weekly.ahram.org.eg/News/27177.aspx .

43 "UN Report: Nature's Dangerous Decline 'Unprecidented'; Species Extinction Rates 'Accelerating'," May 6, 2019, accessible at: https://www.un.org/sustainabledevelopment/blog/2019/05/nature-decline-unprecedented-report/. ${ }^{44}$ The American Security Project's "Climate Security Report" of 2017 is excellent, comprehensive, and can be accessed at: https://www.americansecurityproject.org/climate-security. Its prime virtue is over 50 detailed sections on a wide variety of military relevant subtopics.

${ }^{45}$ Hardin, Garret, "The Tragedy of the Commons," in Science, \#162 (3859): pages 1243-1248, 1968, accessible at: doi:10.1126/science.162.3859.1243. PMID 5699198.

${ }_{46}$ The current organization of Civil Affairs and Psychological Operations units can be reviewed at the website of headquarters, U.S. Army Civil Affairs and Psychological Operations Command (Airborne), which can be found at: https://www.usar.army.mil/Commands/Functional/USACAPOC/USACAPOC-Units/ . 